\title{
Gnathia bermudensis (Crustacea, Isopoda, Gnathiidae), a new species from the mesophotic reefs of Bermuda, with a key to Gnathia from the Greater Caribbean biogeographic region
}

\author{
Kerry A. Hadfield', Nikolaos V. Schizas², Tapas Chatterjee³, Nico J. Smit' \\ I Water Research Group, Unit for Environmental Sciences and Management, North-West University, Private \\ Bag X6001, Potchefstroom, 2520, South Africa 2 University of Puerto Rico at Mayagüez, Department of \\ Marine Sciences, PO Box 9000, Mayagüez, Puerto Rico, 00681, USA 3 Crescent International School, Bario, \\ Govindpur, Dhanbad 828109, Jharkhand, India \\ Corresponding author: Kerry A. Hadfield (kerry.malherbe@nwu.ac.za) \\ Academic editor: T. Horton | Received 30 August 2019 | Accepted 21 October 2019 | Published 21 November 2019 \\ http://zoobank.org/82F35276-BF62-47A2-BCF6-5045351EB6F3 \\ Citation: Hadfield KA, Schizas NV, Chatterjee T, Smit NJ (2019) Gnathia bermudensis (Crustacea, Isopoda, \\ Gnathiidae), a new species from the mesophotic reefs of Bermuda, with a key to Gnathia from the Greater Caribbean \\ biogeographic region. ZooKeys 891: 1-16. https://doi.org/10.3897/zookeys.891.39564
}

\begin{abstract}
Gnathia bermudensis sp. nov. is described from mesophotic coral ecosystems in Bermuda; it is distinguished by pronounced and pointed supraocular lobes, two superior frontolateral processes and a weak bifid mediofrontal process, pereonite 1 not fused dorsally with the cephalosome, and large eyes. This is the first record of a species of Gnathia from Bermuda. A synopsis and key to the other Gnathia species from the Greater Caribbean biogeographic region is provided.
\end{abstract}

\section{Keywords}

Atlantic Ocean, benthic, ectoparasite, Nekton Mission, taxonomy

Copyright Kerry A. Hadfield et al. This is an open access article distributed under the terms of the Creative Commons Attribution License (CC BY 4.0), which permits unrestricted use, distribution, and reproduction in any medium, provided the original author and source are credited. 


\section{Introduction}

Gnathiid isopods are temporary ectoparasites that occur in a variety of habitats ranging in depth, water currents, temperature, climate and salinity (Smit and Davies 2004). The parasitic juveniles feed on the blood and lymph of their fish hosts, while the nonfeeding free-living adults are usually hidden in cavities, corals, or sponges (Hadfield et al. 2009). The taxonomic classification of these isopods is based almost exclusively on the morphology of the adult males, and this makes studies reliant on accurate species identification problematic as males can be difficult to obtain. Currently, there are 12 genera in the family Gnathiidae Leach, 1814 (Smit et al. 2019). Of these, the most speciose genus is Gnathia Leach, 1814, with 126 valid species (Boyko et al. 2008 onwards). To date, there are 14 known species of Gnathia from the Greater Caribbean biogeographic region (see Table 1 for a summary of known information on these species). In 1993, Müller (1993) proposed Gnathia puertoricensis Menzies \& Glynn, 1968 as a junior synonym for $G$. virginalis Monod, 1926 based on the variation in the characters that separated these two species (granulation and tubercles on the anterior pereonites and cephalon). Although not recognised in subsequent publications on gnathiids from this region (George 2003; Farquharson et al. 2012), this synonymisation appears to still be valid and the information regarding both species is combined in Table 1.

Recently, there has been a growing interest in gnathiids from this region specifically regarding their role in cleaner interactions (Artim et al. 2017), food web ecology (Demopoulos and Sikkel 2015), and their role as potential vectors of blood parasites (Cook et al. 2015). However, all of this work has focused on a single species, G. marleyi Farquharson, Smit \& Sikkel, 2012, and therefore it is also the only species from this region with known hosts for the parasitic larval stage. These host fishes include Acanthurus bahianus Castelnau, 1855; Chaetodon capistratus Linnaeus, 1758; Epinephelus guttatus (Linnaeus, 1758); Haemulon flaviolineatum (Desmarest, 1823); H. plumieri (Lacepede, 1801); H. sciurus (Shaw, 1803); Holocentrus rufus (Walbaum, 1792); Lutjanus apodus (Walbaum, 1792); L. griseus (Linnaeus, 1758); Scarus taeniopterus Desmarest, 1831; Sparisoma aurofrenatum (Valenciennes, 1840); Stegastes diencaeus (Jordan \& Rutter, 1897); and S. planifrons (Cuvier, 1830) (see Farquharson et al. 2012).

Bermuda forms part of this Greater Caribbean biogeographic region in the North Atlantic Ocean (Robertson and Cramer 2014). It is situated on the western side of the Sargasso Sea (high salinity, high temperatures and high biodiversity), and has the most northern coral reef system in the world. As part of the Nekton Foundation/XLCatlin Deep-Ocean Survey - Mission 1 (www.nektonmission.org), fish (Stefanoudis et al. 2019a), zooplankton (Stefanoudis et al. 2019b), black corals (Wagner and Shuler 2017), macroalgae (Schneider et al. 2018, 2019) and other benthic communities (NVS pers. obs.) were studied. Macrofaunal collections from mesophotic reef ecosystems of Bermuda (MCEs) contained several specimens of a gnathiid isopod that did not correspond to currently described species. This isopod is here described as a new species of Gnathia and is the first gnathiid isopod to be recorded from Bermuda. 
Table I. Summary of the location, depth, size and references of 15 Gnathia species from the Greater Caribbean biogeographic region, including the 14 previously known species and the new species, Gnathia bermudensis sp. nov.

\begin{tabular}{|c|c|c|c|c|c|}
\hline Species & Location & Depth (m) & Size $(\mathbf{m m})$ & Substratum & References \\
\hline \multirow{8}{*}{$\begin{array}{l}\text { G. beethoveni Paul \& } \\
\text { Menzies, } 1971\end{array}$} & Venezuela & 95 & 3 & mangrove roots; muddy & Paul and Menzies 1971; \\
\hline & & & & and sandy bottoms; algae; & Dias et al. 2013 \\
\hline & & & & seaweed; tunicates; seagrass & \\
\hline & Colombia (Santa Marta) & $13-30$ & & coral rubble & Müller 1988a \\
\hline & Tobago & & & & Kensley and Schotte 1994 \\
\hline & Mexico (Puerto Morelos) & $3-12$ & 1.8 & coral rubble & Monroy-Velázquez and \\
\hline & & & & & Alvarez 2016; Monroy- \\
\hline & & & & & Velázquez et al. 2017 \\
\hline G. bermudensis sp. nov. & Bermuda & $56-90$ & $1.7-2.2$ & $\begin{array}{l}\text { loose gravel and sediment } \\
\text { (associated with corals); } \\
\text { algae; sponges; rodoliths }\end{array}$ & Present study \\
\hline G. brucei George, 2003 & USA (North Carolina) & $1000-1020$ & $2.8-3.2$ & & George 2003 \\
\hline G. calsi Müller, 1993 & $\begin{array}{c}\text { Martinique, French } \\
\text { Antilles }\end{array}$ & $0-2$ & 1.9 & dead corals & Müller 1993 \\
\hline G. gonzalezi Müller, 1988 & Colombia (Santa Marta) & $12-30$ & 1.5 & coral rubble & Müller 1988a \\
\hline G. hemingwayi Ortiz \& & Cuba (Cojímar Bay) & 2 & 3 & wood pile & Ortiz and Lalana 1997 \\
\hline \multicolumn{6}{|l|}{ Lalana, 1997} \\
\hline \multirow[t]{4}{*}{ G. johanna Monod, 1926} & $\begin{array}{l}\text { US Virgin Islands (St. } \\
\text { John) }\end{array}$ & $29-46$ & $2-2.16$ & & Monod 1926; Müller 1988b \\
\hline & Colombia & & & & Kensley and Schotte 1990 \\
\hline & Venezuela & & & seagrass beds; muddy & Díaz et al. 2013 \\
\hline & & & & bottom & \\
\hline G. magdalenensis & Colombia (Santa Marta) & $6-30$ & 2.8 & coral rubble & Müller 1988a \\
\hline \multirow[t]{2}{*}{ Müller, 1988} & Belize & & & & Kensley and Schotte 1989 \\
\hline & Mexico (Puerto Morelos) & $3-12$ & & coral rubble & Monroy-Velázquez et al. 2017 \\
\hline \multirow{4}{*}{$\begin{array}{l}\text { G. marleyi Farquharson, } \\
\text { Smit \& Sikkel, } 2012\end{array}$} & St. John, US Virgin & $3-5$ & $2.6-3.7$ & several host fish & Farquharson et al. 2012 \\
\hline & Islands; Bahamas; British & & & & \\
\hline & Virgin Islands (Guana & & & & \\
\hline & $\begin{array}{c}\text { Island); Puerto Rico; Saba } \\
\text { (Lesser Antilles) }\end{array}$ & & & & \\
\hline G. micheli Ortiz, Winfield & Cuba (Cayo Matias) & 20 & $2.6-3.3$ & algae & Ortiz et al. 2012 \\
\hline \multicolumn{6}{|l|}{ \& Varela, 2012} \\
\hline G. rathi Kensley, 1984 & Belize (Carrie Bow Cay) & $0.5-128$ & $1.6-1.9$ & rubble & Kensley 1984 \\
\hline G. samariensis Müller, & Colombia (Santa Marta) & 30 & 1.7 & coral rubble & Müller 1988a \\
\hline \multicolumn{6}{|l|}{1988} \\
\hline G. triospathiona & USA (Florida) & 200 & 8.8 & & Boone 1918 \\
\hline \multicolumn{6}{|l|}{ Boone, 1918} \\
\hline \multirow[t]{6}{*}{ G. vellosa Müller, 1988} & Colombia (Santa Marta) & $25-30$ & 1.5 & sponges and hydroids & Müller 1988a \\
\hline & Venezuela & & & seagrass beds; mangrove & Dias et al. 2013 \\
\hline & & & & roots; algae & \\
\hline & Mexico (Puerto Morelos) & $6-12$ & 2.7 & coral rubble & Monroy-Velázquez and \\
\hline & & & & & Alvarez 2016; Monroy- \\
\hline & & & & & Velázquez et al. 2017 \\
\hline G. virginalis Monod, 1926 & US Virgin Islands & 29 & 2.2 & & Monod 1926 \\
\hline Syn: G. puertoricensis & Puerto Rico & $0-3$ & 3 & & Menzies and Glynn 1968 \\
\hline \multirow[t]{11}{*}{ Menzies \& Glynn, 1968} & Cuba & & & & Ortiz 1983; Müller 1988a \\
\hline & Belize (Carrie Bow Cay) & & & rubble & Kensley 1984 \\
\hline & Colombia (Santa Marta) & $0-30$ & 2 & coral rubble; under stones; & Müller 1988a \\
\hline & & & & fouling on harbour pilings & \\
\hline & Martinique, French & $0.5-2$ & & seagrass beds; dead corals; & Müller 1993 \\
\hline & Antilles & & & under stones & \\
\hline & Venezuela & & & mangrove roots; seagrass & Dias et al. 2013 \\
\hline & & & & beds; muddy bottom; algae & \\
\hline & Mexico (Puerto Morelos) & $6-12$ & 2.2 & coral rubble & Monroy-Velázquez and \\
\hline & & & & & Alvarez 2016; Monroy- \\
\hline & & & & & Velázquez et al. 2017 \\
\hline
\end{tabular}




\section{Materials and methods}

All benthic samples were collected from 17 July to 14 August 2016 aboard the R/V "Baseline Explorer". Mesophotic benthic surveys and sampling were conducted using Trimix rebreathing divers from the Global Underwater Explorers (GUE) down to $94 \mathrm{~m}$ around the edge of the Bermuda platform. The sampling sites North Northeast (NNE), Plantagenet Bank, Spittal, and Tiger, were selected along the northeast, southeast and southern slopes of the Bermuda platform, respectively (Figure 1). During the same mission, two two-person Triton Class Submersibles (Nomad and Nemo; Vero Beach, FL, United States) equipped with an arm manipulator assisted in sample collection down to $300 \mathrm{~m}$. Divers collected macroalgae, loose gravel, bottom sediment, rhodoliths, sponges, and hard and soft corals to characterise the biodiversity of the Bermudian mesophotic reefs. The depth range for each sample was noted. Once the substrata were brought onto the research vessel, they were placed on a $0.063 \mu \mathrm{m}$ sieve and washed thoroughly with filtered water. Meiofauna and macrofauna associated with the substrata were captured on the $0.063 \mu \mathrm{m}$ sieve and preserved in $>95 \%$ ethanol. The preserved samples were sorted, placed in $95 \%$ ethanol, and stored at $-20{ }^{\circ} \mathrm{C}$ until further processing. Research permits for Bermuda were issued by the Department of Environment and Natural Resources, Bermuda (No. 2016070751).

From these samples, several gnathiids were cleaned and prepared for scanning electron microscopy (SEM; PhenomWorld). Gnathiids were also observed and drawn using an Olympus BX41 compound microscope and an Olympus SZX7 dissecting microscope with a camera lucida. Appendages were removed with the aid of dissecting needles and forceps and stained using lignin pink.

The species description was prepared in DELTA (DEscriptive Language for TAxonomy) using a general Gnathiidae character set (as used in Svavarsson and Bruce 2012). The description is based on the adult male gnathiid. Terminology follows Monod (1926), Cohen and Poore (1994) and Svavarsson and Bruce (2012, 2019). Isopod classification follows that of Brandt and Poore (2003).

Material is deposited in the Natural History Museum of Bermuda.

\section{Taxonomy}

Suborder Cymothoida Wägele, 1989

Superfamily Cymothooidea Leach, 1814

Family Gnathiidae Leach, 1814

\section{Genus Gnathia Leach, 1814, restricted syn.}

Gnathia Leach, 1814: 386-402; Monod 1926: 326-329 (part); Cohen and Poore 1994: 343-346.

Anceus Risso, 1816: 8. 


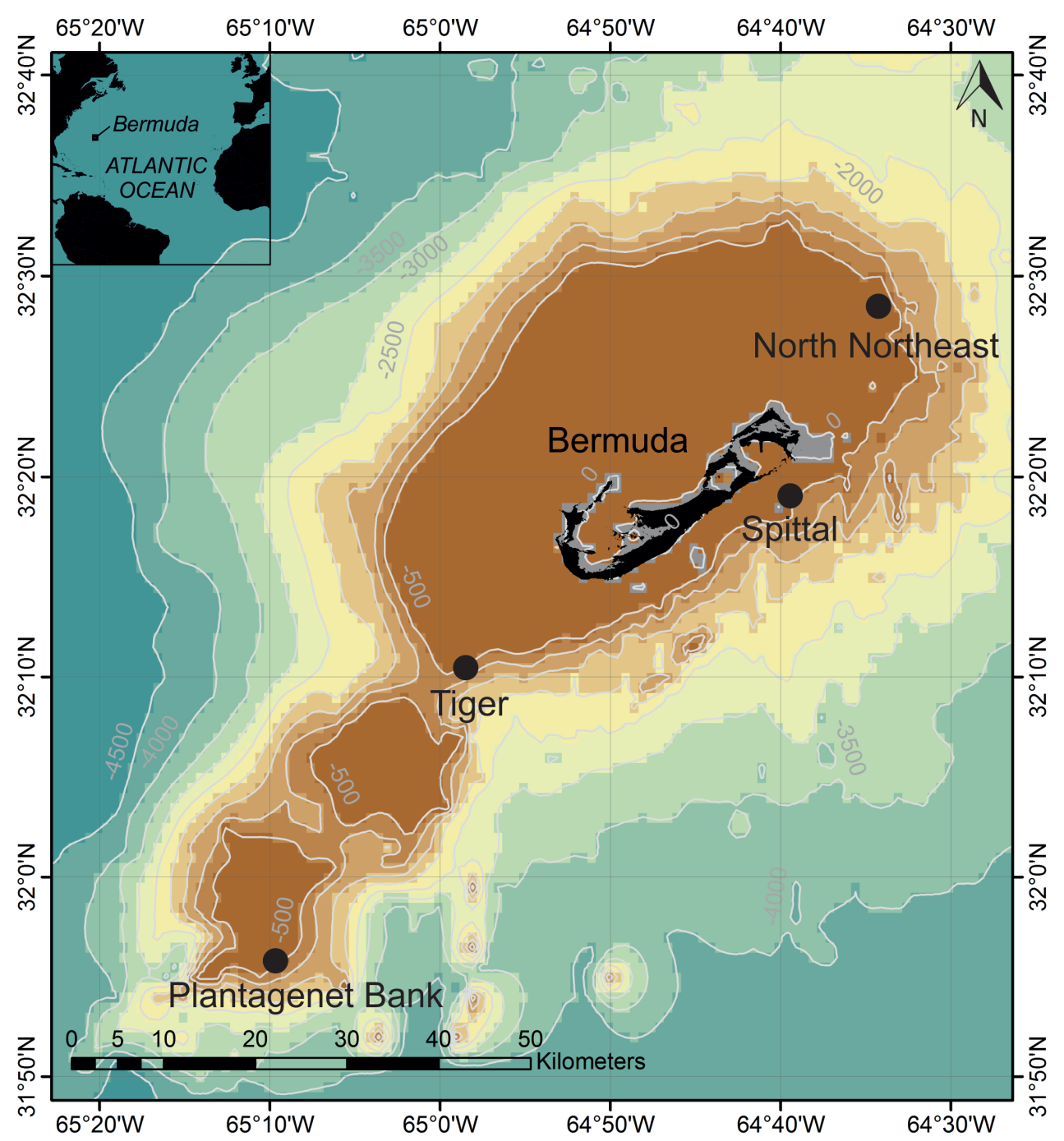

Figure I. Map of collection sites around Bermuda. Data overlay GEBCO_2014 Grid which provides 30 arc-second global grid of elevations. Depth contours in meters.

Praniza Latreille, 1817: 54.

Zuphea Risso, 1826: 104.

Gnathia (Gnathia) s.s.: Monod 1926: 329 (part).

Gnathia (Perignathia): Monod 1926: 554-555 (not Perignathia Monod, 1922).

Type species. Gnathia termitoides Leach, 1814, by monotypy (see Cohen and Poore 1994).

Diagnosis. Frontal margin of cephalosome generally straight (not deeply excavated), with frontal processes. Mandibles not elongate, usually with mandibular incisor and dentate mandibular blade. Paraocular ornamentation and/or a dorsal sulcus may 
be present on cephalosome. Pereonite 1 possibly immersed in cephalosome. Pylopod broad and distinct, with two or three articles, operculate; article 1 enlarged, generally with dense external margin of plumose setae; article 3 reduced or absent.

Remarks. Gnathia can be identified by the presence of frontal processes, a straight frontal border, a broad 2 or 3 articled pylopod, and non-extended mandibles with a dentate blade.

It is the most speciose genus in the family Gnathiidae (currently with 126 valid species). Gnathia is a cosmopolitan genus, commonly found in coral-reef habitats, and its parasitic larvae have been reported from both teleost and elasmobranch hosts (Smit and Davies 2004). The most recent revision of this genus was by Cohen and Poore (1994).

\section{Gnathia bermudensis sp. nov.}

http://zoobank.org/5FD1EC92-2EE5-40E8-8BB8-0C47255A73A2

Figures 2-4

Material examined. Holotype. Bermuda - 1 ते (2.2 mm TL); Plantagenet Bank $\left(31^{\circ} 56.55^{\prime} \mathrm{N}, 65^{\circ} 09.29^{\prime} \mathrm{W}\right) ; 56 \mathrm{~m} ; 12$ Aug 2016; Diver 2, from sediment; Sample ID BEX 2016-449 (BAMZ 2016-338-147).

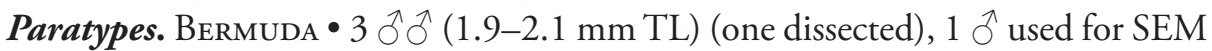
(1.8 mm TL), 1 ㅇ (1.6 mm TL); same info as holotype (BAMZ 2016-338-148).

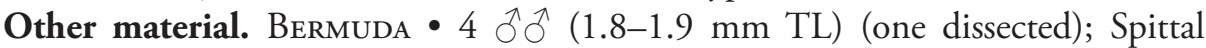
$\left(32^{\circ} 19.119^{\prime} \mathrm{N}, 64^{\circ} 39.437^{\prime} \mathrm{W}\right) ; 45 \mathrm{~m} ; 3$ Aug 2016; sediment from Montastraea cavernosa (Linnaeus, 1767) corals, Divers 39; Sample ID BEX 2016-227, Parent BEX2016225 (sediment from several Montastraea cavernosa colonies) (BAMZ 2016-338-149) • 1 ऽ (2.0 mm TL); NNE (32²8.59'N, 64³4.46'W); 90 m; 4 Aug 2016; Event Divers; Sample ID BEX 2016-250, Parent BEX2016-248 (BAMZ 2016-338-150) • 1 zuphea (Z1) (0.45 mm TL); NNE (32²8.59' N, 64³4.46'W); 4 Aug 2016; algae substrate; Sample ID BEX 2016-251 • 1 ○े used for SEM (1.7 mm TL); Spittal (32¹9.119'N, $\left.64^{\circ} 39.437^{\prime} \mathrm{W}\right)$; from rhodolith collected between 82-152 m; 7 Aug 2016; Dive 22, Nomad 1 (a Triton Submersible); Sample ID BEX 2016-299, Parent BEX2016-0265 - 1 ऽ (2.0 mm TL), 1 q (1.9 mm TL), 1 zuphea (0.8 mm TL); Tiger 4 (32 $11.17^{\prime} \mathrm{N}$, 64⒌36'W); 7 Aug 2016; Divers 12, from sediment; Sample ID BEX 2016-304, Parent BEX2016-0282 (rhodolith with red encrusting sponge, > $40 \mathrm{~m}$ ) (BAMZ 2016-338151) • 2 गे (1.9-2.0 mm TL); Spittal (32 $\left.19.119^{\prime} \mathrm{N}, 64^{\circ} 39.437^{\prime} \mathrm{W}\right) ; 77 \mathrm{~m} ; 11$ Aug 2016; wash from rhodolith; Sample ID BEX 2016-428 • 1 ऽ (2.0 mm TL), 1 praniza (P3) (2.3 mm TL), 1 zuphea (Z1) (0.5 mm TL); Spittal (32 $\left.19.119^{\prime} \mathrm{N}, 64^{\circ} 39.437^{\prime} \mathrm{W}\right)$; 77 m; 11 Aug 2016; Diver 30; Sample ID BEX 2016-430 • 4 zuphea (Z1) (0.5 mm TL); Plantagenet Bank (31 $\left.56.55^{\prime} \mathrm{N}, 65^{\circ} 09.29^{\prime} \mathrm{W}\right) ; 56 \mathrm{~m}$; 12 Aug 2016; Divers 2; Sample ID BEX 2016-450 • 2 ふ઼َ̄ (1.7-1.9 mm TL) (one used for SEM); Plantagenet Bank ( $\left.31^{\circ} 56.55^{\prime} \mathrm{N}, 65^{\circ} 09.29^{\prime} \mathrm{W}\right) ; 56$ m; 12 Aug 2016; Divers 6; Sample ID BEX 2016-451. All samples were collected by GUE technical divers except Sample ID BEX 2016-299, Parent BEX2016-0265, which was collected by a Triton Submersible. 


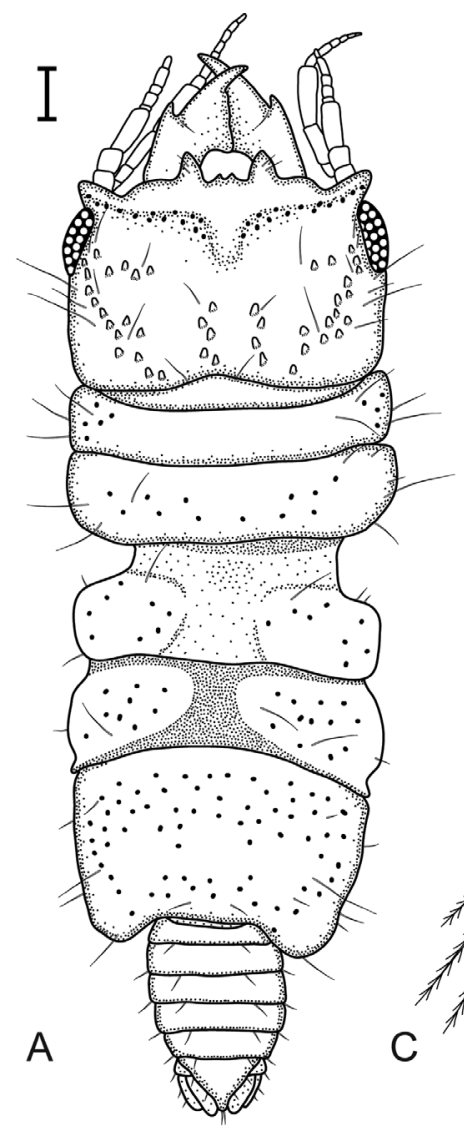

B
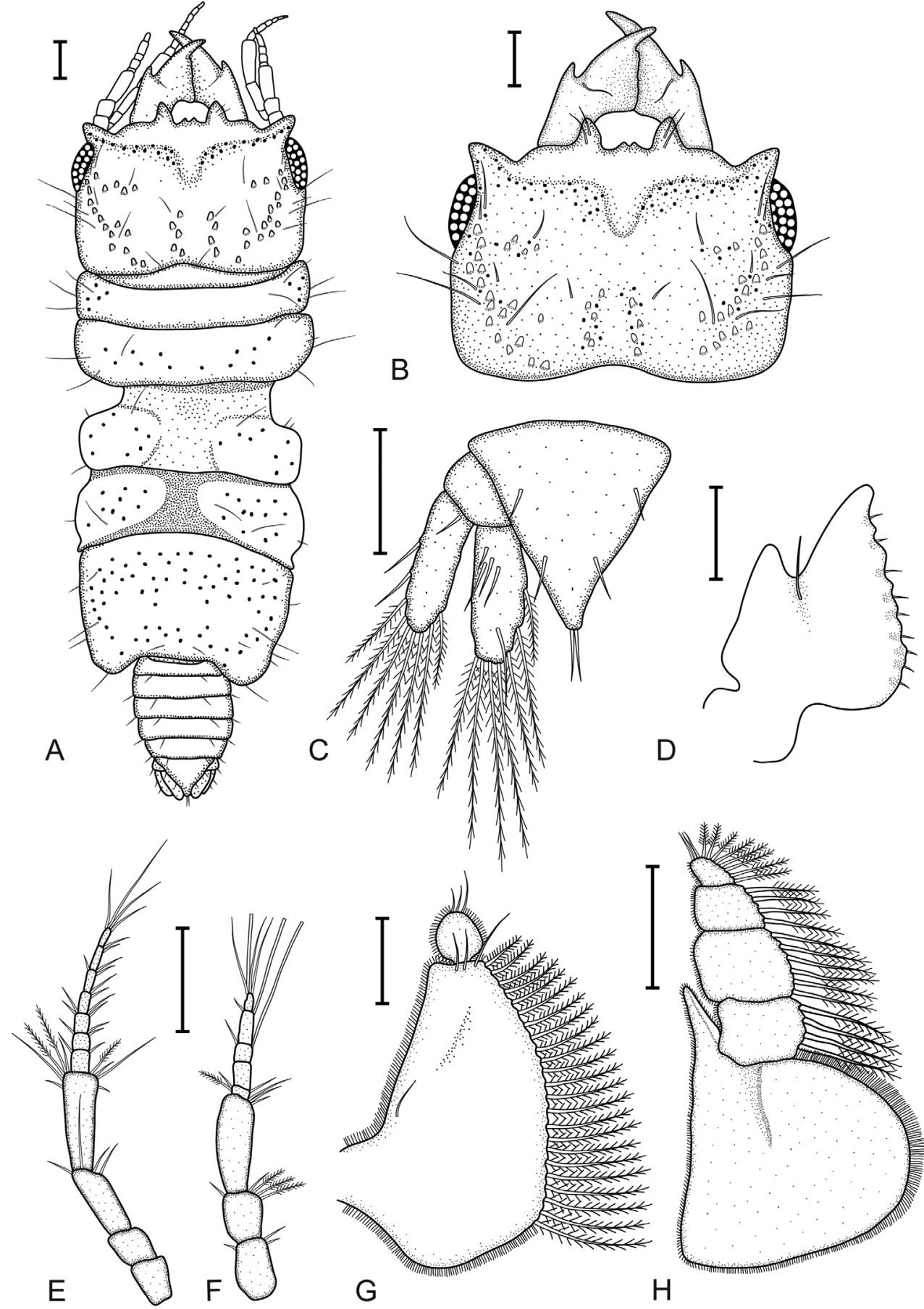

Figure 2. Gnathia bermudensis sp. nov. (BAMZ 2016-338-147), male holotype (2.2 mm TL) A dorsal view $\mathbf{B}$ dorsal view of cephalosome $\mathbf{C}$ dorsal view of pleotelson and uropods $\mathbf{D}$ dorsal view of mandible $\mathbf{E}$ antenna $\mathbf{F}$ antennula $\mathbf{G}$ pylopod $\mathbf{H}$ maxilliped. Scale bars: $100 \mu \mathrm{m}$. 
Description of male. Body 2.3 times as long as greatest width, widest at pereonite 3; dorsal surfaces sparsely punctate, sparsely setose. Cephalosome quadrate, 0.7 as long as wide, lateral margins sub-parallel; dorsal surface with sparse granules; dorsal sulcus narrow, shallow, short; translucent region absent; paraocular ornamentation strongly developed, posteromedian tubercle present. Frontolateral processes present. Frontal margin slightly produced. External scissura present, wide, shallow. Mediofrontal process present, weak, bifid, without fine setae. Supraocular lobe pronounced, pointed; accessory supraocular lobe not pronounced. Superior frontolateral process present, single, strong, conical, with two long simple setae. Inferior frontolateral process absent. Mesioventral margin concave. Eyes present, elongate, 0.3 times as long as cephalosome length, bulbous, standing out from head surface, ommatidia arranged in rows, eye colour black.

Pereon lateral margins subparallel, with few setae; anteriorly with sparse fine granules. Pereonite 1 not fused dorsally with cephalosome; dorsolateral margins fully obscured by cephalosome. Pereonite 2 wider than pereonite 1 . Areae laterales present on pereonite 5. Pereonite 6 without lobi laterales; lobuii weak, globular. Pleon covered in pectinate scales, epimera not dorsally visible on all pleonites. Pleonite 1 lateral margins with one pair of simple setae, with one pair of simple setae medially. Pleotelson as long as anterior width, covered in pectinate scales. Pleotelson lateral margins finely serrate, anterolateral margins weakly convex, with two submarginal setae; posterolateral margin distally weakly concave, with two submarginal setae; apex with two setae.

Antennula peduncle article 20.8 times as long as article 1; article 31.9 times as long as article 2, 2.7 times as long as wide; flagellum 1.1 times as long as article 3, with five articles; article 3 with one aesthetasc seta and one simple seta; article 4 with one aesthetasc seta and one simple seta; article 5 terminating with one aesthetasc seta and three simple setae. Antenna peduncle article 42.5 times as long as wide, twice as long as article 3, and four simple setae; article 51.3 times as long as article 4, 2.8 times as long as wide, inferior margin with three penicillate setae, with six simple setae; flagellum 1.5 times as long as article 5 , with seven articles.

Mandible 0.4 as long as width of cephalosome, triangular, weakly curved, evenly; apex $42 \%$ total length; mandibular seta present. Incisor dentate. Blade present, dentate, weakly convex, dentate along $100 \%$ of margin. Pseudoblade absent; internal lobe absent; dorsal lobe absent; basal neck short; erisma present.

Maxilliped 5-articled; article 1 lateral margin with continuous marginal scale-setae; article 2 lateral margin with four plumose setae; article 3 lateral margin with six plumose setae; article 4 lateral margin with four plumose setae; article 5 with eight plumose setae; endite extending to mid-margin of article 3; without coupling setae.

Pylopod first article 1.5 as long as wide, without distolateral lobe; posterior and lateral margins forming rounded curve; lateral margin with 23 large plumose setae; mesial margin with continuous scale-setae; distal margin with three simple setae; second article 1.1 as long as wide.

Pereopods 2-6 with long simple setae and randomly covered in pectinate scales; pereopod 2 with tubercles on carpus and basis to ischium. Pereopod 2 basis 2.8 times as long as greatest width, superior margin with five setae, inferior margin with two setae; ischium 0.6 times as long as basis, 2.6 as long as wide, superior margin with one seta, 

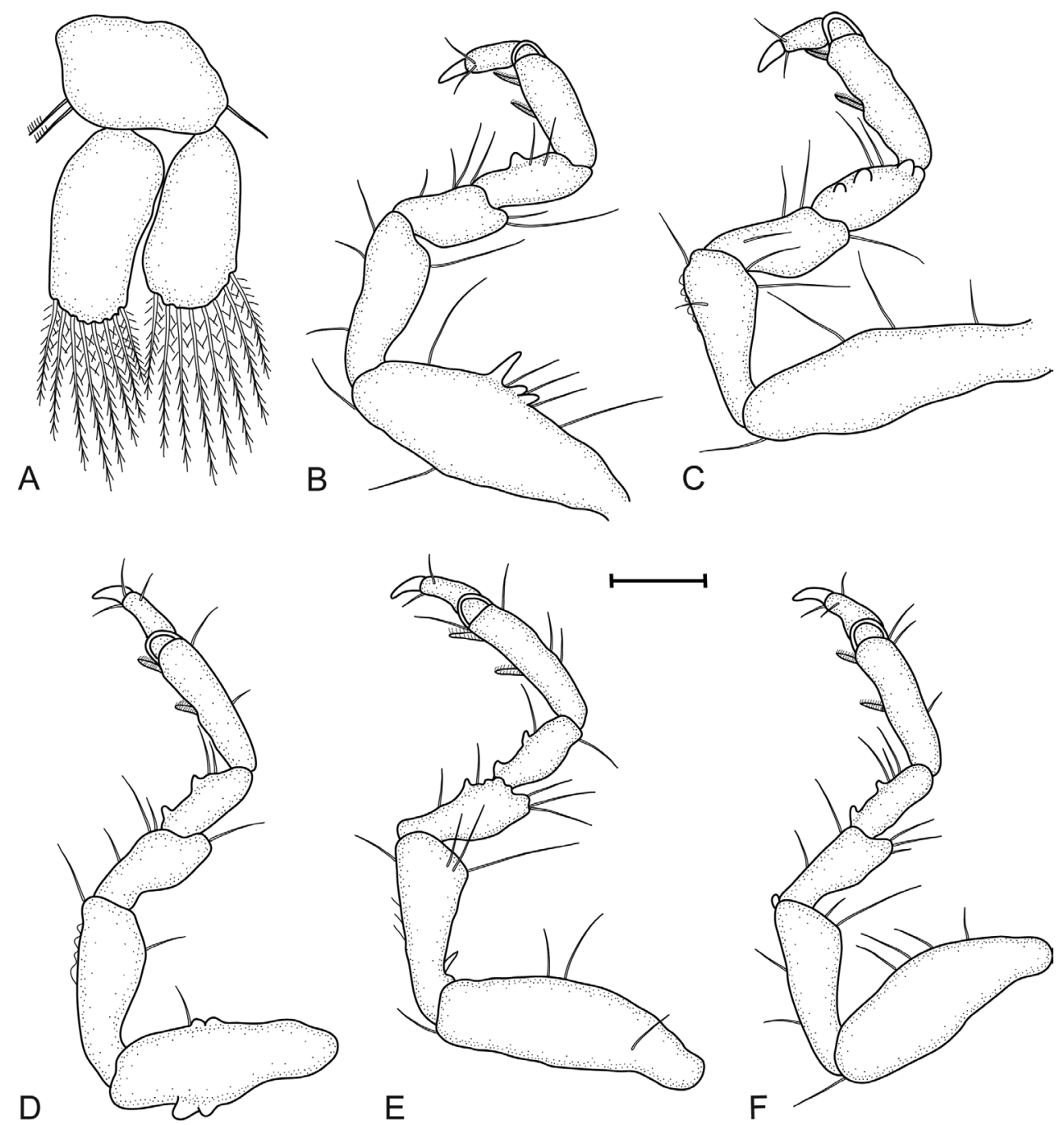

Figure 3. Gnathia bermudensis sp. nov. (BAMZ 2016-338-147), male holotype (2.2 mm TL) A pleopod 2 B-F pereopods 2-6, respectively. Scale bar: $100 \mu \mathrm{m}$.

inferior margin with three setae; merus 0.5 as long as ischium, 1.5 as long as wide, superior margin with two setae, inferior margin with four setae; carpus 0.6 as long as ischium, 1.9 as long as wide, superior margin without setae, inferior margin with two setae; propodus 0.8 times as long as ischium, 2.8 times as long as wide, superior and inferior margins without setae, and two robust setae; dactylus 0.7 as long as propodus. Pereopods 3 and 4 similar to pereopod 2. Pereopod 5 similar to pereopod 6. Pereopod 6 with tubercles on merus and carpus; basis 3.1 times as long as greatest width, superior margin with two setae, inferior margin with two setae; ischium 0.7 as long as basis, 2.7 as long as greatest width, superior margin with three setae, inferior margin with four setae; merus 0.6 as long as ischium, 2.1 times as long as wide, superior margin with three setae, inferior margin with two setae; carpus 0.6 as long as ischium, 1.7 times as 
long as wide, superior margin and inferior margin with one seta; propodus 0.9 as long as ischium, 3.8 times as long as wide, superior margin with three setae, inferior margin with one seta, and two robust setae; dactylus 0.6 as long as propodus.

Penes opening flush with surface of sternite 7.

Pleopod 2 exopod 1.9 as long as wide, distally broadly rounded, with eight plumose setae; endopod 1.9 as long as wide, distally broadly rounded, with eight plumose setae; appendix masculina absent; peduncle 1.5 times as wide as long, mesial margin with two coupling setae, lateral margin with one simple seta.

Uropod rami extending beyond pleotelson, apices narrowly rounded. Uropod endopod 2.4 as long as greatest width, dorsally with five setae; lateral margin straight; proximomesial margin weakly convex, with seven long plumose setae. Uropod exopod not extending to end of endopod, 2.9 times as long as greatest width; lateral margin straight, with two simple setae; proximomesial margin straight, distally convex, mesiodistal margin with seven long plumose setae.

Etymology. The epithet bermudensis is for the country Bermuda, being the first Gnathia record from this island nation.

Distribution. Bermuda.

Hosts. Not known.

Remarks. Gnathia bermudensis sp. nov. may be identified by the produced frontal margin; presence of two superior frontolateral processes; a weak and bifid mediofrontal process; and pronounced and pointed supraocular lobes. The uropod rami extend past the posterior point of the pleotelson; pereonite 1 is not dorsally fused with the cephalosome; large eyes ( 0.3 as long as cephalosome length); and a weakly curved, dentate mandible.

This species is from a moderate depth of 56-90 m and was collected from several habitat types (algae, loose gravel, rhodoliths, sediment associated with scleractinian corals, muddy sand, and sponges) encompassing the mesophotic reef ecosystems of Bermuda. The Mesophotic Coral Ecosystems (MCEs) of Bermuda represent the most northern coral reef systems of the Atlantic; they are visually dominated by scleractinian corals at the upper depth limits, which are replaced gradually at greater depths by rhodoliths, macroalgae beds and fossilised reefs (Goodbody-Gringley et al. 2019). The new gnathiid species has been found on the mesophotic slopes of the main seamount (i.e., the main island of Bermuda) and the smaller seamount Plantagenet (Figure 1); therefore, it is expected to be found throughout the deeper reefs of Bermuda. Only four other species of Gnathia have been collected from greater depths in this region.

Gnathia bermudensis sp. nov. is most similar to G. beethoveni Paul \& Menzies, 1971, G. calsi Müller, 1993, G. johanna Monod, 1926, G. magdalenensis Müller, 1988, and G. virginalis Monod, 1926 from the region. The frontal margin of $G$. beethoveni differs from Gnathia bermudensis in having less pronounced supraocular lobes, four frontolateral processes, a shallow median notch, and the cephalosome is lacking dorsal tubercles. Gnathia calsi also has a deeply notched mediofrontal process with two lobes (and setae), and well developed but angular supraocular lobes, not seen in Gnathia bermudensis sp. nov. Gnathia johanna is narrower than Gnathia bermudensis sp. nov., with less pronounced supraocular lobes and a single convex mediofrontal process (with setae) between the supe- 


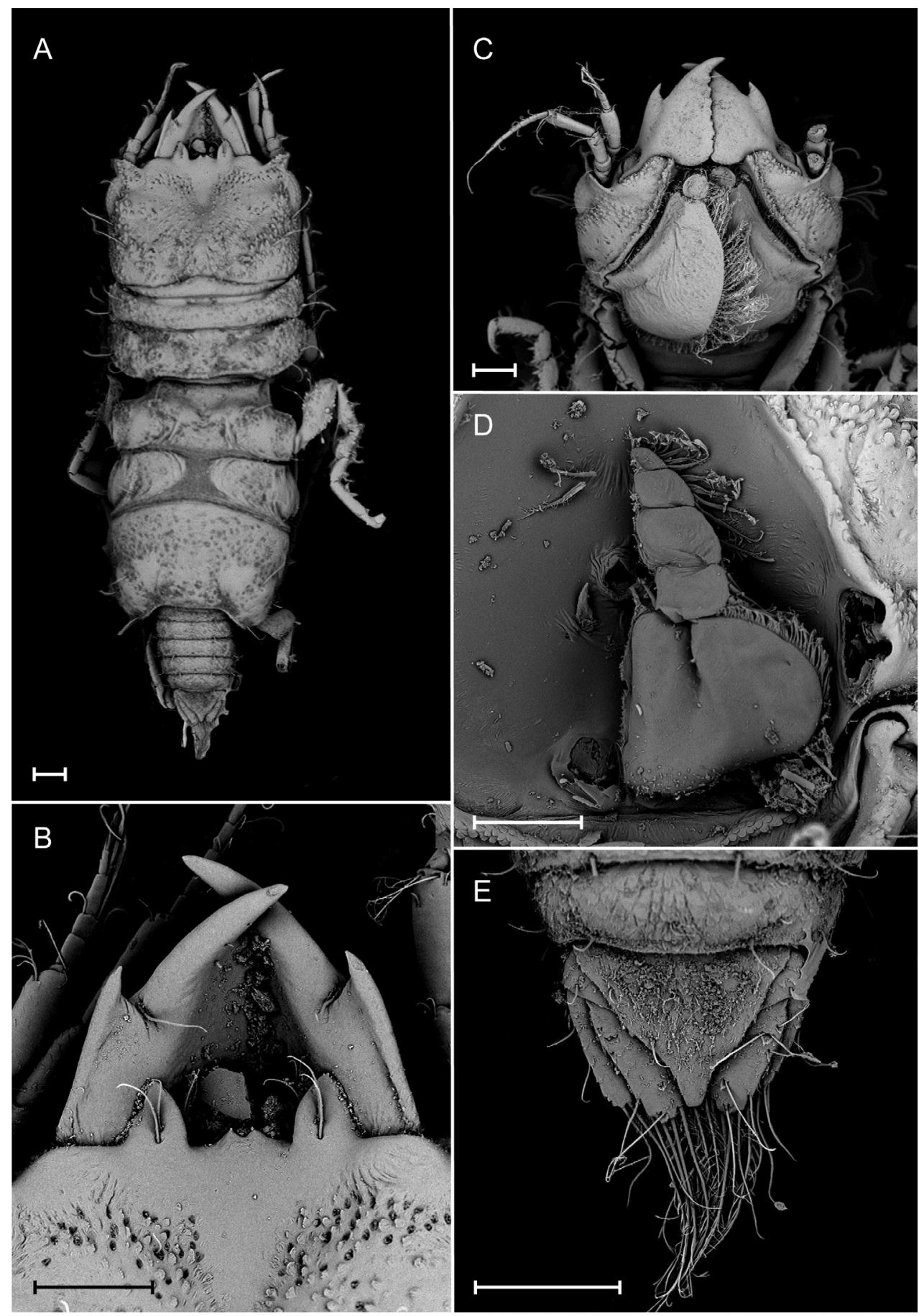

Figure 4. Gnathia bermudensis sp. nov. (BAMZ 2016-338-148), male paratype (1.8 mm TL) Scanning Electron Microscope (SEM) images. A dorsal view B frontal margin and mandibles $\mathbf{C}$ ventral view of cephalosome $\mathbf{D}$ maxilliped $\mathbf{E}$ dorsal view of pleotelson and uropods. Scale bars: $100 \mu \mathrm{m}$. 
rior frontolateral processes. Gnathia magdalenensis and G. virginalis differ from Gnathia bermudensis sp. nov. in having slightly pointed supraocular lobes, a single pointed mediofrontal process with setae, and a longer cephalosome that is fused with pereonite 1 .

Although adult females and zuphea juveniles were collected with the males, they cannot be confidently linked to this species without molecular or ecological data. More collections and rearing of the gnathiid isopods would need to be made in the future for more information and validation of these different life stages, as well as to determine the hosts of the juvenile stages.

\section{Key to members of the genus Gnathia known from the Greater Caribbean biogeo- graphic region}

This key is based on the morphological characters of the adult male:

$1 \quad$ Pereonite 5 elongate (quadrate); located in deeper waters $(\geq 200 \mathrm{~m})$; cephalon frontal border wavy (with 3 bifid frontal lobes or 3 tooth-like projections).....2

- $\quad$ Pereonite 5 similar in shape and size to pereonites 2-4; located in shallower waters $(\leq 200 \mathrm{~m})$; cephalon frontal border with regular frontal processes .... 3 Frontal border produced with large quadrate projection; deep sea (> $1000 \mathrm{~m})$; total body length measuring approximately $2.8-3.2 \mathrm{~mm}$ G. brucei

- $\quad$ Frontal border with deep V-shaped grove; depths below $1000 \mathrm{~m}$ (approx. $200 \mathrm{~m}$ ); total body length measuring approximately $8.8 \mathrm{~mm}$

G. triospathiona

Mediofrontal processes absent. 4 Mediofrontal processes present 10 Anterior margin of cephalon medially concave; robust body; cephalon wider than long and without granules or tubercles..... G. gonzalezi Anterior margin of cephalon not medially concave; slender body; cephalon quadrate.

Only superior frontolateral processes present

Both superior and inferior frontolateral processes present ........................... 7

Frontal margin slightly convex or straight; cephalon granular (tubercles)

G. rathi

Frontal margin convex with 4 medial setae; cephalon without tubercles

G. johanna

Pylopod 2-articled; inferior frontolateral processes smaller in size than superior frontolateral processes Pylopod 3-articled; superior and inferior frontolateral processes similar in size

Cephalon and body without granules or tubercles; sparsely setose

G. beethoveni

- Cephalon with granules or tubercles; few to many slender setae over the body 
9 Supraocular lobes not well developed; narrow pleon and pleotelson longer than wide; pereonites 5 and 6 not clearly defined................. G. hemingwayi

- $\quad$ Supraocular lobes well developed; pleon with short setae and wider than long; pereonites 5 and 6 clearly defined .................................................... calsi

$10 \quad$ Mediofrontal process bifid ...................................................................11

Mediofrontal process not bifid .............................................................12

11 Frontal margin medially concave; superior frontolateral processes weak with 3 or 4 simple setae on each process; supraocular lobe not pronounced.....

G. marleyi

- $\quad$ Frontal margin produced; superior frontolateral processes strong with 2 simple setae on each process; supraocular lobe pronounced and pointed

G. bermudensis sp. nov.

12 Cephalon with few or no granules or tubercles.........................................13

- $\quad$ Cephalon with many small tubercles (finely granular).................................14

13 Mediofrontal process with 2-4 simple setae; mandible with inner lobe

G. magdalenensis

- $\quad$ Mediofrontal process without any setae; mandible without inner lobe

G. samariensis

14 Cephalon approximately 1.7 times as wide as long; mandibular carina distally

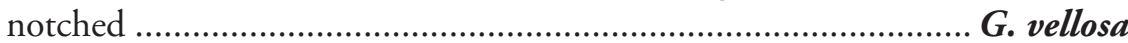

- Cephalon approximately 1.2 times as wide as long; mandibular carina distally rounded

G. virginalis

\section{Acknowledgments}

The authors and the Nekton Mission would like to thank SR Smith, J Pitt, T Trotts, and C Flook from the Bermudian Government for their assistance, advice and participation in the XL-Catlin Deep-Ocean Survey Bermuda Mission. We would also like to thank the crew and technicians of the Baseline Explorer, Brownies Global Logistics, and Triton Submersibles. This is contribution number 14 for Nekton and contribution number 355 for the NWU Water Research Group.

\section{References}

Artim JM, Hook A, Grippo RS, Sikkel PC (2017) Predation on parasitic gnathiid isopods on coral reefs: a comparison of Caribbean cleaning gobies with non-cleaning microcarnivores. Coral Reefs 36: 1213-1223. https://doi.org/10.1007/s00338-017-1613-6

Boone PL (1918) Description of ten new isopods. Proceedings of the United States National Museum 54: 591-604.

Brandt A, Poore GCB (2003) Higher classification of the flabelliferan and related Isopoda based on a reappraisal of relationships. Invertebrate Systematics 17: 893-923. https://doi. org/10.1071/IS02032 
Boyko CB, Bruce NL, Hadfield KA, Merrin KL, Ota Y, Poore GCB, Taiti S, Schotte M, Wilson GDF (Eds) (2008 onwards) World Marine, Freshwater and Terrestrial Isopod Crustaceans database. Gnathia Leach, 1814. Accessed through: World Register of Marine Species. http://www.marinespecies.org/aphia.php?p=taxdetails\&id=118437 [on 2019-07-10]

Cohen BF, Poore GCB (1994) Phylogeny and biogeography of the Gnathiidae (Crustacea: Isopoda) with descriptions of new genera and species, most from South-Eastern Australia. Memoirs of the Museum of Victoria 54: 271-397. https://doi.org/10.24199/j.mmv.1994.54.13

Cook CA, Sikkel PC, Renoux LP, Smit NJ (2015) Blood parasite biodiversity of reef-associated fishes of the eastern Caribbean. Marine Ecology Progress Series 533: 1-13. https://doi. org/10.3354/meps 11430

Demopoulos AWJ, Sikkel PC (2015) Enhanced understanding of ectoparasite-host trophic linkages on coral reefs through stable isotope analysis. International Journal for Parasitology: Parasites and Wildlife 4: 125-134. https://doi.org/10.1016/j.ijppaw.2015.01.002

Díaz YJ, Martín A, Herrera J (2013) Diversidad de isópodos (Crustacea: Isopoda) del Parque Nacional Morrocoy, Venezuela, y clave de identificación. Boletín del Instituto Oceanográfico de Venezuela 52: 33-60.

Farquharson C, Smit NJ, Sikkel PC (2012) Gnathia marleyi sp. nov. (Crustacea, Isopoda, Gnathiidae) from the Eastern Caribbean. Zootaxa 3381: 47-61. https://doi.org/10.11646/ zootaxa.3381.1.3

George RY (2003) Two new species of gnathiid isopod Crustacea from the North Carolina coast. Journal of the North Carolina Academy of Science 119: 33-40.

Goodbody-Gringley G, Noyes T, Smith SR (2019) Mesophotic Coral Ecosystems of Bermuda. In: Loya Y, Puglise KA, Bridge TCL (Eds) Mesophotic Coral Ecosystems (MCEs). Springer International Publishing, 31-45. https://doi.org/10.1007/978-3-319-92735-0

Hadfield KA, Smit NJ, Avenant-Oldewage (2009) Life cycle of the temporary fish parasite, Gnathia pilosus (Crustacea: Isopoda: Gnathiidae) from the east coast of South Africa. Journal of the Marine Biological Association of the United Kingdom 89: 1331-1339. https:// doi.org/10.1017/S0025315409000587

Kensley B (1984) The Atlantic Barrier Reef Ecosystem at Carrie Bow Cay, Belize, III: New marine Isopoda. Smithsonian Institution Press, Washington, DC, 81 pp. https://doi. org/10.5479/si.01960768.24.1

Kensley B, Schotte M (1989) Guide to the marine isopod crustaceans of the Caribbean. Smithsonian Institution Press, Washington D.C., 308 pp. https://doi.org/10.5962/bhl.title.10375

Kensley B, Schotte M (1994) Marine isopods from the Lesser Antilles and Colombia (Crustacea: Peracarida). Proceedings of the Biological Society of Washington 107: 482-510.

Latreille PA (1817) Les Crustacés, les Arachnides, et les Insectes. In: Cuvier G (Ed.) Le Règne Animal, distribué d'après son organisation, pour servir de base à l'histoire naturelle des animaux et d'introduction à l'anatomie comparée. Vol. 3. D’Eterville, Paris, 653 pp. https:// doi.org/10.5962/bhl.title.41460

Leach WE (1814) Crustaceology. In: Brewster's Edinburgh Encyclopedia. 7: 383-437. https:// doi.org/10.5962/bhl.title.30911

Menzies RJ, Glynn PW (1968) The common marine isopod Crustacea of Puerto Rico: A handbook for marine biologists. Martinus Nijhoff, The Hague, Netherlands, 133 pp. 
Monod T (1926) Les Gnathiidæ. Essai monographique (morphologie, biologie, systématique). Mémoires de la Société des Sciences Naturelles du Maroc 13: 1-668.

Monroy-Velázquez V, Alvarez F (2016) New records of isopods (Crustacea: Peracarida: Isopoda) from the Mesoamerican Reef at Puerto Morelos, Quintana Roo, Mexico. Check List 12: 1938. https://doi.org/10.15560/12.4.1938

Monroy-Velázquez V, Rodríguez-Martínez RE, Alvarez F (2017) Taxonomic richness and abundance of cryptic peracarid crustaceans in the Puerto Morelos Reef National Park, Mexico. PeerJ 5: e3411. https://doi.org/10.7717/peerj.3411

Müller H-G (1988a) The genus Gnathia Leach (Isopoda) from the Santa Marta area, northern Colombia, with a review of Gnathiidea from the Caribbean Sea and Gulf of Mexico. Bijdragen tot de Dierkunde 58: 88-104. https://doi.org/10.1163/26660644-05801008

Müller H-G (1988b) Redescription of Gnathia johanna Monod, 1926 (Isopoda) from St. John, Virgin Islands. Bulletin Zoölogisch Museum Universiteit van Amsterdam 11(15): 129-135.

Müller H-G (1993) Marine Isopoda from Martinique, French Antilles: Cirolanidae and Gnathiidae (Crustacea: Cymothoidea). Cahiers de Biologie Marine 34: 29-42.

Ortiz M (1983) Guía para la identificación de los isópodos y tanaidáceos (Crustacea: Peracarida), asociados a los pilotes de las aguas Cubanas. Revista de Investigaciones Marinas 4: 3-20.

Ortiz M, Lalana R (1997) Gnathia hemingwayi especie nueva (Isopoda, Gnathiidea) de la costa noroccidental de Cuba. Revista de Investigaciones Marinas 18: 21-26.

Ortiz M, Winfield I, Varela C (2012) First records of peracarid crustaceans from the Cayo Matias Ocean Blue Hole, SW Cuba, with the description of two new species. Zootaxa 3505: 53-66. https://doi.org/10.11646/zootaxa.3505.1.4

Paul AZ, Menzies RJ (1971) Sub-tidal isopods of the Fosa de Cariaco, Venezuela, with descriptions of two new genera and twelve new species. Boletin de Instituto Universidade Oriente 10: 29-48.

Risso A (1816) Histoire naturelle des Crustacés des environs de Nice. Paris: Librairie GrecqueLatine-Allemande. 175 pp. https://doi.org/10.5962/bhl.title.8992

Risso A (1826) Histoire naturelle des principales productions de l'Europe méridionale et particulièrement de celles des environs de Nice et des Alpes Maritimes, vol. 5. FG Levrault, Paris, 403 pp. https://doi.org/10.5962/bhl.title.58984

Robertson DR, Cramer KL (2014) Defining and dividing the Greater Caribbean: Insights from the biogeography of shorefishes. PLoS ONE 9(7): e102918. https://doi.org/10.1371/ journal.pone.0102918

Schneider CW, Lane CE, Saunders GW (2018) A revision of the genus Cryptonemia (Halymeniaceae, Rhodophyta) in Bermuda, western Atlantic Ocean, including five new species and C. bermudensis (Collins \& M. Howe) comb. nov. European Journal of Phycology 53: 350-368. https://doi.org/10.1080/09670262.2018.1452297

Schneider CW, Popolizio TR, Saunders GW (2019) Collections from the mesophotic zone off Bermuda reveal three species of Kallymeniaceae (Gigartinales, Rhodophyta) in genera with transoceanic distributions. Journal of Phycology 55: 414-424. https://doi.org/10.1111/ jpy. 12828

Smit NJ, Davies AJ (2004) The curious life-style of the parasitic stages of gnathiid isopods. Advances in Parasitology 58: 289-391. https://doi.org/10.1016/S0065-308X(04)58005-3 
Smit NJ, Bruce NL, Hadfield KA (2019) Parasitic Crustacea: State of knowledge and future trends. Springer International Publishing, 481 pp. https://doi.org/10.1007/978-3-030$17385-2$

Stefanoudis PV, Gress E, Pitt JM, Smith SR, Kincaid T, Rivers M, Andradi-Brown DA, Rowlands G, Woodall LC, Rogers AD (2019a) Depth-dependent structuring of reef fish assemblages from the shallows to the rariphotic zone. Frontiers in Marine Science 6 p. 357. https://doi.org/10.3389/fmars.2019.00307

Stefanoudis PV, Rivers M, Ford H, Yashayaev IM, Rogers AD, Woodall LC (2019b) Changes in zooplankton communities from epipelagic to lower mesopelagic waters. Marine Environmental Research 146: 1-11. https://doi.org/10.1016/j.marenvres.2019.02.014

Svavarsson J, Bruce NL (2012) New and little-known gnathiid isopod crustaceans (Cymothoida) from the northern Great Barrier Reef and the Coral Sea. Zootaxa 3380: 1-33. https:// doi.org/10.11646/zootaxa.3380.1.1

Svavarsson J, Bruce NL (2019) New gnathiid isopod crustaceans (Cymothoida) from Heron Island and Wistari Reef, southern Great Barrier Reef. Zootaxa 4609: 31-67. https://doi. org/10.11646/zootaxa.4609.1.2

Wagner D, Shuler A (2017) The black coral fauna (Cnidaria: Antipatharia) of Bermuda with new records. Zootaxa 4344: 367-379. https://doi.org/10.11646/zootaxa.4344.2.11 